\title{
Effects of Pruning and Plant Spacing on the Growth and Yield of Watermelon (Citrullus lanatus L.) in Unwana-Afikpo
}

\author{
Oga, I. O. ${ }^{1}$, Umekwe, P. N. ${ }^{2}$ \\ Department of Agricultural Technology, School of Industrial Technology \\ Akanu Ibiam Federal Polytechnic, Unwana - Afikpo, P.M.B 1007, Afikpo, Ebonyi State, Nigeria
}

\begin{abstract}
The experiment was conducted to evaluate the effects of pruning and plant spacing on the growth and yield of watermelon (Citrullus lanatus L.) in Unwana-Afikpo, Ebonyi State. It was conducted as $2 \times 3$ factorial laid out in randomized complete block design (RCBD). The treatment comprised of two pruning methods (pruning and non-pruning) and three different plant spacing (50cm $x 40 \mathrm{~cm}$, $50 \mathrm{~cm} \times 50 \mathrm{~cm}$ and $50 \mathrm{~cm} \times 60 \mathrm{~cm})$. Each treatment was replicated four times and the parameters measured were: vine length, number of leaves, number of flowers, days to $50 \%$ anthesis, number of fruits, weight of fruits and total yield. The results showed that spacing at $50 \mathrm{~cm} \times 60 \mathrm{~cm}$ significantly increased the number of leaves and $50 \%$ anthesis. Spacing at $50 \mathrm{~cm} \times 60 \mathrm{~cm}$ was the adequate measurement for minimizing days to $50 \%$ flowering (37.19 days) and maximizing total number of fruits (2.94), weight of fruits (3.03kg) and total yield $(7.57 \mathrm{~kg} / \mathrm{ha})$. Plant spacing at $50 \mathrm{~cm} \times 40 \mathrm{~cm}$ consistently gave the least values in all the yield parameters measured except on the number of fruits. The pruned plants produced the longest vine $(90.14 \mathrm{~cm})$ number of leaves $(15.78)$, number of flowers (10.31) and number of fruits (2.63). It is recommended that farmers in Unwana-Afikpo should use the spacing $50 \mathrm{~cm} \times 60 \mathrm{~cm}$ and adopt pruning as one of the cultural practices in raising the crop for maximum production.
\end{abstract}

Keywords: watermelon, spacing, growth, yield

\section{Introduction}

Watermelon is a member of Cucurbitaceae family, which also includes Squash, Cucumber, Muskmelons, Gourds and Pumpkins. Individual plants of watermelon produce both male and female flowers and the size of the fruit varies from 2 to $14 \mathrm{~kg}$, depending on the variety. Watermelon grows as a vine that sends out long runners along the ground. Watermelon is successfully grown under cold temperature. The best average temperature for watermelon production is between $18^{\circ} \mathrm{C}$ and $35^{\circ} \mathrm{C}$. Above $35^{\circ} \mathrm{C}$ or below $16^{\circ} \mathrm{C}$ temperature will slow the growth and affect the crops maturity. Watermelon does well on sandy loam or silt loamy soils. Sandy soils have limited water-holding capacities and must be carefully watered and fertilized to allow for high yield potential. Soil $\mathrm{pH}$ ranges from 5.8 to 6.6 is ideal for watermelon production. Watermelon serves as food for human consumption. It is a fruit that provides large amount of vitamins, minerals and antioxidants at low amount of calories. It contains fiber which encourages healthy digestion. The consumption of watermelon decreases the risk of obesity and overall mortality, diabetes and heart diseases. Vegetables constitute a major source of nitrate, providing more than $85 \%$ of the average daily human dietary intake [1]. Watermelons are warm season annuals and are less tolerant to cold weather than other Cucurbits like Cucumber and Cantaloupe. They have long prostrate vines and thus, require a lot of garden space for good yield [2]. It requires well-drained soils that are rich in organic matter with water retention capacity [3]. The seeds are rich in fat and protein and are eaten as snacks and also added to other dishes or used as an oil seed.
Table 1: Nutritional values of watermelon (Citrullus lanatus L.) for $100 \mathrm{~g}$

Source: [4]

\begin{tabular}{|l|l|}
\hline Nutrients & Quantities \\
\hline Energy & $30 \mathrm{kcal}$ \\
\hline Carbohydrate (g) & 7.55 \\
\hline Sugar (g) & 6.20 \\
\hline Dietary fiber (g) & 0.40 \\
\hline Fat (g) & 0.15 \\
\hline Protein (g) & 0.61 \\
\hline
\end{tabular}

Watermelon is an excellent source of vitamin C $(8.1 \mathrm{mg})$ and vitamin A (10\%). It also provide significant amount of vitamin $\mathrm{B}$, as well as minerals such as potassium $(\mathrm{K})$, magnesium $(\mathrm{Mg})$, iron $(\mathrm{Fe})$, manganese $(\mathrm{Mn})$, phosphorus $(\mathrm{P})$, sodium $(\mathrm{Na})$ and zinc $(\mathrm{Zn})$ [5]. The leaves and fruits are utilized as green vegetables [6]. Watermelon is spaced widely in the farm, though bush varieties that require less spacing are gradually introduced into cultivation. It is desired largely as a refreshing source of tasty water and utilizes large amount of moisture to produce juicy flesh [2]. Some farmers who embark on large scale production of watermelon lack cultural practices like pruning in its production. Efforts are required for appropriate cultural practice, for sustainable production of watermelon. Pruning is an act of cutting off plant branches so as to encourage flowering or fruiting. Shoots, flowers and fruits are pruned to maintain a proper balance between the vegetative growth and fruit load. This will maximize production [7]. Plant growth and other factors can be modified by pruning to suit human needs and desires. Watermelon vine pruning treatments can serve these purposes: to enhance mechanical harvesting, production of hybrid seed, ease of control of pests and diseases, use of higher plant population without 


\section{International Journal of Science and Research (IJSR) \\ ISSN (Online): 2319-7064 \\ Index Copernicus Value (2013): 6.14 | Impact Factor (2015): 6.391}

significant yield reduction and the production of uniform fruits $[8,9]$. Branch production has been reported to be the most important contributor to young leaf and immature pod yields in both recent and traditional cultivars of Cucumber $[10,11]$. [12] observed that the removal of the lateral shoot had a positive effect on the total yield of Cucumber. They noted that pruning the lateral runner near the base of the plant will result in higher yield. [13] reported that the removal of the lateral shoot had a positive effect on total yield of bitter gourd. Without pruning, most of the female flowers occur between the $4^{\text {th }}$ and $10^{\text {th }}$ nodes or at a height of $0.5-2.0 \mathrm{~m}$ [14]. In a trail on the effect of pruning on the yield of Cucumber, [15] noted that pruning had no effect on the length and weight of fruits of Cucumber. Pruned Cucumber had higher weight of fruits than the unpruned ones. Similar result was obtained in a pruning study on Cucumber variety "Poung" [16]. Studies on apical bud and leaf removal of Okra showed that the treatments enhanced the vegetative growth and development [17]. [18] observed that unpruned Cucumber flowered three days earlier than the pruned ones. He observed that in Cucumber, unpruned treatment produced the highest total yield while the pruned treatment produced low marketable yield. Pruning produced the highest total yield, marketable and non-marketable yield of cucumber [16]. A field trial was carried out to determine the effect of pruning and spacing on a commercial variety "Amata 765". [19] reported that the highest total yield was obtained from unpruned treatment. Pruning all the branches on the main stem or pruning the branches up to node ten decreased the number of non-marketable yield. [20] reported that the number of fruits, marketable and non marketable cucumber was highest on the unpruned treatment than on the one stem pruning. Work done by [21] on the effect of planting density on the yield and fruit quality of two melon hybrids revealed that there was significant interaction among pruning and hybrid for medium weight of fruits, total soluble solids, total number of fruits and number of unmarketable fruits. The hybrids subjected to pruning produced longer fruits and the highest level of total soluble solids. The effect of pruning on the growth and yield of Okra showed that pruning significantly delayed fruiting by $8-10$ days, extended the length of harvest duration by 12 - 15 days, increased number of pods per plant by $10-40 \%$ and pod yield by $9-36 \%$ more than the controlled plants [22].

In the production of watermelon, plant spacing is a major problem faced by farmers in their production. The use of spacing in crop production is very important and good because it reduces competition between plants and weeds. When adequate spacing is done in plant production, it increases crop growth and yield. Generally, in Watermelon, the yield and number of fruits per unit area increased with increased crop density, whereas the yield and number of fruits per plant decreased [23, 24]. High planting density increased the number of fruits per area [23, 25]. However, some studies showed that average weight of fruits decreases with increase in plant density. [24, 26]. Competition for water and nutrients in dense plant stands might be responsible for the decrease in plant growth and yield [27]. One of the most important factors in flourishing crop plant is correct spacing because it allows plant to develop to their full potential above and underneath the ground. Adequate space ensures less competition for sunlight, water and

fertilizer. Spacing also prevents the spread of pests and diseases from one plant to another [28]. Vine length, diameter of fruits, number of leaves and branches increased with an increase in spacing [29, 30]. A field trial was carried out to determine the effect of staking and plant spacing on the growth and yield of Cucumber (Cucumis sativus L.), [31, 32,33 ] noted that increase in plant spacing also increased fruit yield. Suitable plant spacing can lead to optimum yield but incorrect plant spacing could result in relatively low yield and poor quality fruits [34, 35]. Dense plant populations may result in rigorous growth, poor quality fruits and low yield due to intra-specific competition [36]. The study is to evaluate the effects of pruning and plant spacing on the growth and yield of watermelon (Citrullus lanatus L.) in Unwana, Ebonyi State.

\section{Materials and Methods}

\subsection{Experimental Site}

The experiment was conducted at the Teaching, Demonstration and Research Farm (TDR) of the Department of Agricultural Technology, Akanu Ibiam Federal Polytechnic, Unwana. The length and width of the experimental field was $14.5 \mathrm{~m} \times 11 \mathrm{~m}$, giving a total land area of $159.5 \mathrm{~m}^{2}$. The experimental field was divided into four equal blocks, and each block consisted of six sub-plots giving a total of twenty-four sub-plots. Each plot measured $2 \mathrm{~m} \times 2 \mathrm{~m}$ with $1 \mathrm{~m}$ between adjacent blocks and $0.5 \mathrm{~m}$ between adjacent plots. Raised beds were manually cultivated. The experiment was conducted as 2 x 3 factorial laid out in randomized complete block design (RCBD) with four replications of each treatment. The treatment comprised of two pruning and three plant spacing treatments.

\subsection{Land preparation}

The experimental field was manually cleared with cutlass and field beds of $2 \mathrm{~m} \times 2 \mathrm{~m}$ were made with hoe.

\subsection{Planting}

Watermelon seeds were planted by direct seeding at various plant spacing $(50 \mathrm{~cm} \mathrm{x} 40 \mathrm{~cm}, 50 \mathrm{~cm} \mathrm{x} 50 \mathrm{~cm}$ and $50 \mathrm{~cm} \mathrm{x}$ $60 \mathrm{~cm})$. The variety "sugar baby" was sown two seeds per hill at a depth of $1.5 \mathrm{~cm}$.

\subsection{Fertilizer Application}

NPK 15:15:15 fertilizer was applied at the rate of $100 \mathrm{~kg} / \mathrm{ha}$ as a blanket treatment. This was done three weeks after planting.

\subsection{Crop Protection}

Weeding was done manually using hand hoe and Zap (pesticide) was used at 3th, 4th and 5th week after planting to protect the plants against insects such as Lady birds, Aphids, White flies, Thrips and Melon fly.

\subsection{Pruning}

\section{Volume 5 Issue 4, April 2016}




\section{International Journal of Science and Research (IJSR) \\ ISSN (Online): 2319-7064 \\ Index Copernicus Value (2013): 6.14 | Impact Factor (2015): 6.391}

The plants were pruned at fourth week after planting. Secateurs were used to prune the main branch of the plant.

\subsection{Harvesting}

Harvesting of Watermelon fruits commenced at the ninth week after planting. It was done by hand picking when the dull green colour on the fruits changed to glossy green.

\subsection{Data Collections}

Data were collected on the growth parameters (vine length, number of leaves, number of flowers, number of days to $50 \%$ flowering) and yield components such as number of fruits, weight of fruits, and total yield were taken from the four tagged plants per plot. The four tagged plants were selected from the center plants of each plot. Fruit yield was calculated thus:

Total yield $(\mathrm{kg} / \mathrm{ha})=\underline{\text { weight of fruits/plot } \mathrm{x} 10,000 \mathrm{~m}^{2}}$ Area of plot $\mathrm{x} 1,000 \mathrm{~kg}$

\subsection{Statistical Analysis}

Statistical analysis of data was based on the procedure outlined by [37] for factorial experiment in Randomized Complete Block Design (RCBD). Separation of treatment means for significant effect was as described by [38].

\section{Results}

Table 2: Effect of pruning, plant spacing and their interaction on the vine length $(\mathrm{cm})$

\begin{tabular}{|lllll|}
\hline & \multicolumn{4}{c|}{ Plant spacing (cm) } \\
\cline { 2 - 5 } Pruning & $50 \times 40$ & $50 \times 50$ & $50 \times 60$ & Mean \\
\hline P0 & 45.38 & 68.60 & 72.00 & 61.99 \\
P1 & 106.19 & 76.25 & 87.97 & 90.14 \\
\hline Mean & 75.79 & 72.43 & 79.99 & \\
\hline LSD $_{0.05}$ & Pruning & $=$ & N.S \\
LSD $_{0.05}$ & Plant spacing & $=$ & N.S \\
LSD $_{0.05}$ & Interaction & $=$ & N.S \\
\hline
\end{tabular}

The effect of plant spacing, pruning and their interaction had non-significance on the production of watermelon Table 2. Plant spacing at $50 \mathrm{~cm} \times 60 \mathrm{~cm}$ produced the longest vine $(79.99 \mathrm{~cm})$ while the lowest $(72.43 \mathrm{~cm})$ was at plant spacing of $50 \mathrm{~cm} \times 50 \mathrm{~cm}$.

Pruned treatment produced the longest vine $(90.14 \mathrm{~cm})$ while non pruned plants produced the lowest vine $(61.99 \mathrm{~cm})$ Table 2.

Pruning at plant spacing interaction had no significant effect on watermelon production. Plant spacing at $50 \mathrm{~cm} \times 40 \mathrm{~cm}$ on pruning produced the longest vine while the $50 \mathrm{~cm} \mathrm{x} 40 \mathrm{~cm}$ on non pruned plants gave the lowest vine.
Table 3: Effect of pruning, plant spacing and their interaction on the number of leaves produced

\begin{tabular}{|lllll|}
\hline & \multicolumn{4}{c|}{ Plant spacing (cm) } \\
\cline { 2 - 4 } Pruning & $50 \times 40$ & $50 \times 50$ & $50 \times 60$ & Mean \\
\hline$P_{0}$ & 9.83 & 8.65 & 14.79 & 11.09 \\
$P_{1}$ & 16.88 & 14.46 & 16.01 & 15.78 \\
\hline Mean & 13.36 & 11.56 & 15.40 \\
\hline LSD $_{0.05}$ & Pruning & $=$ & 3.36 \\
LSD $_{0.05}$ & Plant spacing & $=$ & N.S \\
LSD $_{0.05}$ & Interaction & $=$ & N.S \\
\hline
\end{tabular}

Plant spacing had no significant effect at $\mathrm{P}=0.05$ on the production of watermelon. Plant spacing at $50 \mathrm{~cm} \times 60 \mathrm{ccm}$ produce the highest number of leaves (15.40) while the lowest number of leaves $(11.56)$ was at $50 \mathrm{~cm}$ x $50 \mathrm{~cm}$.

Pruning had significant effect at $\mathrm{P}=0.05$ Table 3. Pruned treatment produced the highest number of leaves (15.78) while non pruned plant produced the lowest number of leaves (11.09) Tables 3 and differed significantly from each other.

Pruning at plant spacing interaction had non-significant effect on watermelon production. Plant spacing at $50 \mathrm{~cm} \mathrm{x}$ $40 \mathrm{~cm}$ on pruning (16.88) produced the highest number of leaves while the $50 \times 50 \mathrm{~cm}$ on non-pruned plant (8.65) gave the lowest number of leaves Table 3.

Table 4: Effect of pruning, plant spacing and their interaction on the number of flowers produced

\begin{tabular}{|lllll|}
\hline & \multicolumn{4}{c|}{ Plant spacing } \\
\cline { 2 - 4 } Pruning & $50 \times 40$ & $50 \times 50$ & $50 \times 60$ & Mean \\
\hline $\mathrm{P}_{0}$ & 2.88 & 5.20 & 7.88 & 5.32 \\
$\mathrm{P}_{1}$ & 11.25 & 9.19 & 10.50 & 10.31 \\
\hline Mean & 7.07 & 7.19 & 9.19 \\
\hline LSD $_{0.05}$ & Pruning & $=$ & N.S \\
LSD $_{0.05}$ & Plant spacing & $=$ & N.S \\
LSD $_{0.05}$ & Interaction & $=$ & N.S \\
\hline
\end{tabular}

The effects of plant spacing, pruning and their interaction had no significant influence on the production of watermelon Table 4. Plant spacing at $50 \mathrm{~cm} x \quad 60 \mathrm{~cm}$ produced the highest number of flowers (9.19) while the lowest (7.07) was at plant spacing of $50 \mathrm{~cm} \times 40 \mathrm{~cm}$. Number of flowers increased as plant spacing increased from 50 x 40 to $50 \mathrm{~cm} \times 60 \mathrm{~cm}$.

Pruned treatment produced the highest number of flowers (10.31) while non-pruned plant produced the lowest flowers (5.22) Table 4.

Pruning at plant spacing interaction had no significant effect on watermelon production. Plant spacing at $50 \mathrm{~cm} \mathrm{x} 40 \mathrm{~cm}$ on pruning (11.25) produced the highest number of flowers while the $50 \mathrm{~cm} \times 40 \mathrm{~cm}$ on non pruned plant (2.88) gave the lowest number of flowers Table 4 . 


\section{International Journal of Science and Research (IJSR) \\ ISSN (Online): 2319-7064 \\ Index Copernicus Value (2013): 6.14 | Impact Factor (2015): 6.391}

Table 5: Effect of pruning, plant spacing and their interaction on $50 \%$ anthesis

\begin{tabular}{|lcccc|}
\hline & \multicolumn{3}{c|}{ Plant spacing (cm) } & \\
\cline { 2 - 4 } Pruning & $50 \times 40$ & $50 \times 50$ & $50 \times 60$ & Mean \\
\hline $\mathrm{P}_{0}$ & 38.00 & 38.25 & 38.00 & 38.08 \\
$\mathrm{P}_{1}$ & 37.13 & 37.00 & 36.38 & 36.84 \\
\hline Mean & 37.57 & 37.63 & 37.19 & \\
\hline LSD $_{0.05}$ & Pruning & $=$ & 1.318 & \\
LSD $_{0.05}$ & Plant spacing & $=$ & N.S & \\
LSD $_{0.05}$ & Interaction & $=$ & N.S & \\
\hline
\end{tabular}

Plant spacing had no significant effect at $\mathrm{P}=0.05$. Plant spacing at $50 \mathrm{~cm} \times 50 \mathrm{~cm}$ produced the longest days to $50 \%$ anthesis (37.63 days) while the earliest bud break which occurred at (37.19 days) was at $50 \mathrm{~cm} \times 60 \mathrm{~cm}$. Number of days to $50 \%$ anthesis was statistically the same in all plant spacing ie did not differ from each other. Number of days $50 \%$ anthesis increased as plant spacing increased from $50 \mathrm{~cm} \times 40 \mathrm{~cm}$ to $50 \mathrm{~cm} \times 50 \mathrm{~cm}$ beyond which there was a decrease.

Pruning had significant effect on the number of days to $50 \%$ flowering Table 5. Non pruned plant (38.08days) gave the longest days to $50 \%$ anthesis while the earliest bud break was at pruned plants (36.84 days) Table 5 and they differed significantly from each other.

At pruning at plant spacing interaction spacing at $50 \mathrm{~cm} \mathrm{x}$ $50 \mathrm{~cm}$ gave the longest days to $50 \%$ anthesis on non-pruned plant (38.25 days) while spacing of $50 \mathrm{~cm} \times 60 \mathrm{~cm}$ on pruned treatment gave the earliest bud break (36.38 days) Table 5.

Table 6: Effect of pruning, plant spacing and their interaction on number of fruits

\begin{tabular}{|lllll|}
\hline & \multicolumn{4}{c|}{ Plant spacing (cm) } \\
\cline { 2 - 4 } Pruning & $50 \times 40$ & $50 \times 50$ & $50 \times 60$ & Mean \\
\hline $\mathrm{P}_{0}$ & 2.75 & 1.75 & 3.13 & 2.54 \\
$\mathrm{P}_{1}$ & 2.75 & 2.38 & 2.75 & 2.63 \\
\hline Mean & 2.75 & 2.07 & 2.94 & \\
\hline LSD $_{0.05}$ & Pruning & $=$ & N.S \\
LSD $_{0.05}$ & Plant spacing & $=$ & N.S \\
LSD $_{0.05}$ & Interaction & $=$ & N.S \\
\hline
\end{tabular}

The effect of plant spacing, pruning and their interaction had no significant effect on the production of watermelon Table 6. Plant spacing at $50 \mathrm{~cm} \times 60 \mathrm{~cm}$ produced the highest number of fruits (2.94) while the least (2.07) was at plant spacing of $50 \mathrm{~cm} \times 50 \mathrm{~cm}$.

Pruned treatment produced the highest number of fruits (2.63) while non pruned plants produced the lowest number of fruits (2.54) Table 6.

Pruning at plant spacing interaction had no significant effect on watermelon production Table 6 . Plant spacing of $50 \mathrm{~cm} \mathrm{x}$ $60 \mathrm{~cm}$ at non-pruned treatment produced the highest number of fruits (3.13) while the $50 \mathrm{~cm} \times 50 \mathrm{~cm}$ on non-pruned plant also gave the lowest number of fruits (1.75).
Table 7: Effect of pruning, plant spacing and their interaction on weight of fruits $(\mathrm{kg})$

\begin{tabular}{|lllll|}
\hline & \multicolumn{3}{c|}{ Plant spacing $(\mathrm{cm})$} & \\
\cline { 2 - 4 } Pruning & $50 \times 40$ & $50 \times 50$ & $50 \times 60$ & Mean \\
\hline$P_{0}$ & 2.94 & 2.61 & 3.39 & 2.98 \\
$\mathrm{P}_{1}$ & 2.38 & 2.96 & 2.66 & 2.67 \\
\hline Mean & 2.66 & 2.79 & 3.03 & \\
\hline LSD $_{0.05}$ & Pruning & $=$ & N.S & \\
LSD $_{0.05}$ & Plant spacing & $=$ & N.S & \\
LSD $_{0.05}$ & Interaction & $=$ & 13.13 & \\
\hline
\end{tabular}

Plant spacing had no significant effect at $\mathrm{P}=0.05$ on the production of watermelon. Plant spacing at $50 \mathrm{~cm} \times 60 \mathrm{~cm}$ gave the heaviest fruits $(3.03 \mathrm{~kg}$ ) while the lowest weight of fruits $(2.66 \mathrm{~kg})$ was at $50 \mathrm{~cm} \times 40 \mathrm{~cm}$. The weight of fruits increased as plant spacing increased from $50 \mathrm{~cm} \times 40 \mathrm{~cm}$ to $50 \mathrm{~cm} \times 60 \mathrm{~cm}$. The heaviest weight of fruits was produced at $50 \times 60 \mathrm{~cm}$ and was statistically similar with other plant spacing.

Unpruned plant gave the heaviest weight of fruits $(2.98 \mathrm{~kg})$ while the lowest weight was at pruned plants $(2.67 \mathrm{~kg})$ Table 8. Weights of fruits on pruned plant were statistically the same with weights of fruits on unpruned plants Table 7.

Pruning at plant spacing interaction had significant effect at $\mathrm{P}=0.05$ table 7 . At pruning and plant spacing interaction, spacing at $50 \mathrm{~cm} \times 60 \mathrm{~cm}$ gave the heaviest fruits at unpruned plants $(3.39 \mathrm{~kg}$ ) while spacing at $50 \mathrm{~cm} \times 40 \mathrm{~cm}$ at pruned treatment produced the least weight $(2.38 \mathrm{~kg})$ Table 7 . They are statistically similar.

Table 8: Effect of pruning, plant spacing and their interaction on the total yield $(\mathrm{kg} / \mathrm{ha})$

\begin{tabular}{|l|l|l|l|l|}
\hline & \multicolumn{4}{|c|}{ Plant spacing (cm) } \\
\hline Pruning & $50 \times 40$ & $50 \times 50$ & $50 \times 60$ & Mean \\
\hline $\mathrm{P}_{0}$ & 7.35 & 6.54 & 8.47 & 7.45 \\
$\mathrm{P}_{1}$ & 5.96 & 7.41 & 6.66 & 6.68 \\
\hline Mean & 6.66 & 6.98 & 7.58 & \\
\hline LSD $_{0.05}$ & Pruning $=$ & N.S \\
LSD $_{0.05}$ & Plant spacing $=$ & N.S \\
LSD $_{0.05}$ Interaction $=$ & N.S \\
\hline
\end{tabular}

The effect of plant spacing, pruning and their interaction had no significant effect on the production of watermelon Table 8 . Plant spacing at $50 \mathrm{~cm} \times 60 \mathrm{~cm}$ produced the highest yield (7.58kg/ha) while the lowest $(6.66 \mathrm{~kg} / \mathrm{ha})$ was at plant spacing of $50 \mathrm{~cm} \times 40 \mathrm{~cm}$ Table 8 . Total yield increased as plant spacing increased from $50 \mathrm{~cm} \times 40 \mathrm{~cm}$ to $50 \mathrm{~cm} \times 60 \mathrm{~cm}$.

Non-pruned treatment produced the highest yield $(7.45 \mathrm{~kg} / \mathrm{ha})$ while pruned plant gave the lowest yield (6.68kg/ha) Table 8.

Plant spacing at $50 \mathrm{~cm} \times 60 \mathrm{~cm}$ on the non pruned plants produced the highest yield $(8.47 \mathrm{~kg} / \mathrm{ha})$ while the $50 \mathrm{x} 40 \mathrm{~cm}$ on the pruned plants $(3.96 \mathrm{~kg} / \mathrm{ha})$ gave the lowest yield. 


\section{Discussion}

\subsection{Vegetative Growth}

Spacing at $50 \mathrm{~cm} \times 60 \mathrm{~cm}$ produced the highest number of vines, highest number of leaves and number of flowers. The number of flowers was highest at plant spacing $50 \mathrm{~cm} \mathrm{x}$ $60 \mathrm{~cm}$ and lowest at $50 \mathrm{~cm} \times 40 \mathrm{~cm}$. Number of flowers increased as the plant spacing increased. This is conformity with report by [29, 30] who observed that vegetative parameters increased with an increase in spacing of melon. The pruned treatment produced the longest vines, highest number of leaves and number of flowers while number of days to $50 \%$ anthesis was highest on the unpruned plants. The pruned plants had an earlier bud break than the nonpruned treatment. This is not in conformity with the observation made by [18] who reported that unpruned Cucumber flowered three days earlier than the pruned ones. $[17,39]$ however reported that studies on apical bud and leaf removal in Okra have demonstrated that these treatments enhanced Okra vegetative growth and its development.

\subsection{Yield}

The highest total number of fruits, weight of fruits, and total yield was obtained at plant spacing $50 \mathrm{~cm} \times 60 \mathrm{~cm}$. Weight of fruits and total yield increased as plant spacing increased from $50 \mathrm{~cm} \times 40 \mathrm{~cm}$ to $50 \mathrm{~cm} \times 60 \mathrm{~cm}$. This is in agreement with the work done by [32, 34] who noted that increase in plant spacing also increased fruit yield. Suitable plant spacing can lead to optimum yield but increase in plant spacing could result in relatively low yield and poor quality fruits [35, 36]. Dense plant population may result in rigorous growth, poor quality fruits and low yield due to intraspecific competition [36]. Plant spacing at $50 \mathrm{~cm} \mathrm{x} 60 \mathrm{~cm}$ gave the highest values in all the yield parameters. This is in conformity with the work done by $[23,25]$ who observed that high planting density increased number of fruits per area. The pruned plants gave higher values in number of fruits while unpruned plants produced the heaviest fruits and total yield $(\mathrm{kg} / \mathrm{ha})$. This is inconformity with the work done by [16] who observed that pruning produced the highest total yield, marketable and non marketable yield of Cucumber. [12] observed that the removal of the lateral shoot had a positive effect on the total yield of Cucumber. They noted that pruning the lateral runner near the base of the plant will result in higher yield. Similar observation was made by [13] who reported that the removal of lateral shoot had a positive effect on total yield of bitter gourd. [40, 41] also found that suitable plant spacing with pruning gave higher yield in Cucumber production.

\section{Conclusion and Recommendation}

In this experiment, plant spacing and pruning had a positive effect on the growth and yield of watermelon. Spacing at $50 \mathrm{~cm} \times 60 \mathrm{~cm}$ proved to be the required spacing for getting higher number of fruits per hectare. There is need to prune watermelon as it enhances its production. From our observation in the field experiment, we recommend that farmers in Unwana-Afikpo, Ebonyi State who intend to embark on massive production of watermelon should use spacing at $50 \mathrm{~cm} \times 60 \mathrm{~cm}$ and adopt pruning as one of the cultural practices in raising the crop for maximum production.

\section{References}

[1] Gangoli, SD, Brandt PA., Ferom VJ and Koeman C Biological and analytical aspect of soil. Ghent Belgium, 1982.

[2] George, A Horticulture, principles and practice second edition, 2004.

[3] Lawal, AB Response of cucumber to intercropping with maize and varying rates of farmyard manure and inorganic fertilizer, Agriculture and Environment 2000; 2 (1): 78-83.

[4] USDA (National Nutrient Database for Standard Reference Released 19th November, 2002).

[5] Wikipedia Free encyclopedia. http;//en.wikipedia.org/w/index 2013.

[6] Vonwyk, VE and Gericke, N Peoples plant. Briza, Pretoria. 2000; Pp. 24-28.

[7] Wayne Vandre Greenhouse cucumber production. University of Alaska. Fair Banks Cooperative Extension Service 1990

[8] Jarrick, J Training and pruning. Hort. Sci: 1986; p 400.

[9] Humphries, EG and Vermillion, DL Picking cucumber vine pruning treatments and their implications for mechanical harvesting. Transitions of the ASAE, USA. 1994; 37 (1): 71-75.

[10] Olasantan, FO Apical short harvests growth and fruit yield of pumpkin (Cucubita maxima L.) Journal of Vegetable Science._1988; 12: 78-87.

[11] Olasantan, FO Optimum plant populations for okra Abelmoschus esculentus) in a mixture with cassava (Manihot esculentum) and its relative 2001.

[12] Douglas, C, Sanders, U and Larry, M Home garden trellised cucumber. College of Agriculture and life science, North Carolina State University. Horticultural Information leaflet 2001; 80114-13.

[13] Palada, MC and Chang, LC Suggested cultural practices for bitter gourd, AVRDC, 2003; (3): 547.

[14] Rasco, AO and Castillo, SO Flowering pattern and vine pruning effects in bitter gourd. Philipine Agriculturist. 1990; 73: 3-4.

[15] Doung, Hoa-Xa. Effect of pruning on the yield and quality of cucumber. AVRDC. Training-Report: Kasetsart University, Bangkok, Thailand 1999; P. 31.

[16] Than Xuan Dao Pruning effect on the yield of cucumber varieties "poung" ARCH Training 1995; 2pp.

[17] Olasantan, FO Apical short harvests growth and fruit yield of pumpkin (Cucubita maxima L.) Journal of Vegetable Science._1988; 12: 78-87.

[18] Than, Than Nu. Pruning effect on the yield of different cucumber varieties AVRDC, Myanmar 1996; p 51.

[19]Hong, Q Effect of pruning and staking on yield and quality of cucumber, AVRDC Training Report, Chima, 2000; 7pp.

[20] Okafor, CG Effect of staking and pruning on the vegetable growth and yield of cucumber. Unpublished undergraduate projects. Ebonyi State University, Abakaliki, 2007; 95 pp. 


\section{International Journal of Science and Research (IJSR) \\ ISSN (Online): 2319-7064}

Index Copernicus Value (2013): 6.14 | Impact Factor (2015): 6.391

[21] Francisco, PFH, Nogneria, ICC, Pedrosa, F, Negreiros, MZ and Bazeira Neto Pruning of main stem and plant density on yield and fruit quality of melon by hybrids. Horticultural Brasileira. 2003; 21 (2): 191-196.

[22] Olasantan, FO and Salan, AW Effect of pruning on growth leaf yield and pod yield of okra (Abelmoschus esculentus L. Moench) Journal of Agricultural Science. 2007; 146 : $33-102$.

[23] Nesmith, DS Plant spacing influences watermelon yield and yield components. Hort. Science 1993; 28: 885-887.

[24] Motsenbocker, CE and Arancibia, RA In row spacing influences triploid watermelon yield and crop values. Hort. Technology_2002; 12: 437-440.

[25] Duthie, JA, Roberts, BW, Edelson, JV and Shrefler, JW Plant density - dependent variation in density, frequency and size of watermelon fruits1999a.

[26] Sanders, DC, Cure, JD and Schultheis, JR Yield response of watermelon to planting density, 1999.

[27] Knavel, DE Growth, development and yield potential of short intemode muskmelon. J. Amer. Soc. Hort. Sci.1988; 113:595-599.

[28] Celac Proper crop spacing for higher crop yields. World press. Comm./category/farmer to-farmer-advise 2011; p. 3.

[29] Dean, B, Milijana, G and Borsic, J Plant spacing and cultivar effect on melon growth and yield component. Procedings of American Society of Horticultural Science 2004; 109: 238-243.

[30] Mangala, R and Mausia, S Handbook of Agriculture 2006; pp 169.

[31] Hirata, SL and Tilato, $\mathbf{R}$ Comparative cost of Tee Pee - Trellised Vs Non - trellised cucumber production. Economic Information Report_EL - 95-1 2000; pp 4046.

[32] Nelson, $\mathbf{H}$ Effects of population density on fruits and seeds production in muskmelon Acta Horticulture. 2005; 38 (3): 15-23.

[33] Paulo, S, Lima, S, Jailtan, FR, Jaedson, CAM and Jacverson, DAS Plant density and fruit of muskmelon. Rer. Bras Pratic. 25 (2): Jabsticabal 2003.

[34] Absar, N and Siddique, MA Influence of plant density on the yield of three varieties of okra._Bangladesh. J. Agric. 1982; 7:15-21

[35] Moniruzzama, M, Uddin, MZ, and Chaudhury, AK Response of okra seed crop to sowing time and plant spacing in south eastern hilly region of Bangladesh. Bangladesh. J. Agriculture Res._2007; 32 (3): 393-402.

[36] Talukder, MAH, Munnaf, MA, Alam, MK, Salam, MA and Amin, MMU Influence of sowing time, Plant spacing and picking interval on the growth and yield of okra. Pakistan J. of Biol. Sci. 2003; 6 (18):1626-1630.

[37] Steel, RG and Torrie, JH Principle and procedure of statistics. A Biometrical Approach. 2nd Ed MC - Graw Hill. Inc. New York 1980; 633 pp.

[38] Obi, IU Fixed and Random Treatment Models in Analysis of Variance for Balanced Designs. Department of Crop Science, University of Nigeria, Nsukka. Star prints and publishing Co, Enugu, Nigeria, 2001; 38 pp.

[39] Schippers, RR African Indigenous Vegetables.Overview Of the cultivated specie Chathan, UK:Natural Resource Institute/ACP-Cornell University Ithaca, New York, 2000.
[40] Dykun, VP and Schevchuk, AA Influence of nutritional area on the productivity of bee-pollinating and parthenocarpic cucumber hybrids in the spring plastic hothouses. Ways of intensifying the vegetable growing Kiev, Russia Federation, 1990; pp 65-68.

[41] More, TA, Chandra, P, Majundar, G and Singh, JK Some observation on growing cucumber under plastic greenhouse. In: Proceeding of $11^{\text {th }}$ International Congress on the use of Plastic in Agriculture, New Delhi \& India, $26^{\text {th }}$ February $-2^{\text {nd }}$ March, 1990; P 4955. 